\title{
Productivity and Quality of Wheat as Affected by Long-Term Addition of Fertilizers and Amendments: A Review
}

\author{
Neha Chauhan*, N.K. Sankhyan, R.P. Sharma and Gourav \\ Department of Soil Science, CSK Himachal Pradesh Krishi Vishvavidyalaya, \\ Palampur-176062, India \\ *Corresponding author:
}

\section{Keywords}

Wheat, fertilizers, FYM, amendments, yield, quality

Article Info

Accepted:

22 December 2019

Available Online:

20 January 2020

\section{A B S T R A C T}

Wheat (Triticum aestivum L.) is the most widely produced cereal and one of the most important staple cereal crop for the majority of the world's population. Wheat grains are important source of protein and wheat flour has unique dough forming properties. The quality of wheat flour can be measured by parameters such as protein, moisture, gluten, fat, ash, carbohydrates and mineral nutrients. Chapatti is the major wheat product consumed in India. However, due to urbanization and industrialization, the demand for bread, biscuit and other related products is increasing whose quality is governed by unique properties of dough formed from the wheat flour with optimized grain protein content and other quality constituents. Therefore, it is important to combine the high grain yields with better grain quality to meet the twin challenges of nutritionally superior and high quality wheat products. This paper reviews about the productivity and quality of wheat as affected by addition of fertilizers and manures.

\section{Introduction}

Wheat is the second most important cereal after rice. It is one of the most staple food crops consumed by more than one third of the world population due to the presence of high calories. Wheat is not only a nutritious grain, but is also a rich source of proteins, minerals and dietary fibre (Oluwatoyin et al., 2015). Wheat is also used in brewing for the production of ethanol and wheat beer, as a raw material for cosmetics, wheat protein as a substitute for meat, to make wheat straw composites and also as fodder for domestic animals (Leo et al., 2012).

The nutritional value of wheat is extremely important as it takes an important place among the few crop species being extensively grown as staple food sources. The importance of wheat is mainly due to the fact that its seed can be ground into flour, semolina, etc., 
which form the basic ingredients of bread and other bakery products, as well as pastas, and thus it presents the main source of nutrients to the most of the world population (Sramkovaa et al., 2009). The grain quality depends on the content of organic compounds (protein and its fractions, carbohydrates, and fat), mineral nutrients (phosphorus, calcium, potassium, magnesium, and microelements), vitamins, antioxidants, and antinutritional compounds (Mallick et al., 2013; Poudel and Bhatta 2017).

The content and the properties of starch are very important, including the basic components of amylase and amylopectin. They determine the technological and nutrition quality of grains (Zhang et al., 2017). A special biological and performance function is played by protein, especially the gluten fraction. Gliadin and glutenin ensure dough elasticity and extensibility (Singh and Khatkar 2005). Gluten determines softness, elasticity, and cohesion of bread both fresh and after storage (Curti et al., 2014).

Nutrient balance is one of the key components to increase crop productivity and quality. Excess and imbalanced use of nutrients have caused nutrient mining, declined crop productivity and ultimately deteriorated the soil health which is also reflected in the quality of the produce. Replenishment of these nutrients through organics and a combination of organics and inorganics has a direct impact on soil health and crop productivity. Continuous use of inorganic fertilizers in imbalanced manner leads to deterioration in soil physical, chemical and biological properties and ultimately the soil health.

The deteriorating soil health, declining soil organic matter content and increasing micronutrient deficiencies have put a big question mark on the sustainability of wheat production. However, contribution of chemical fertilizers towards an increase in agricultural production is well known. But, their injudicious use exhibits a detrimental effect on soil health. Long-term use of FYM with inorganic fertilizers is a good management system in accumulating soil organic carbon, sustaining yield and enhancing soil quality for increasing crop production. This paper reviews about the productivity and quality of wheat as affected by long-term addition of fertilizers and manures.

Brief resume of research work pertinent to the investigation entitled, "Productivity and quality of wheat as affected by long-term addition of fertilizers and amendments" has been reviewed in under the following heads:

I. Effect of fertilizers and amendments on wheat productivity

II. Effect of fertilizers and amendments on wheat quality

\section{Effect of fertilizers and amendments on wheat productivity}

Tiwari et al., (2002) studied the long-term influence of organic and inorganic fertilization on productivity of soybean-wheat system in Typic Haplusterts of Jabalpur (Madhya Pradesh) and concluded that application of recommended dose of inorganic fertilizer along with manure at the rate of $15 \mathrm{t} \mathrm{ha}^{-1}$ helped in sustaining the yields of soybean and wheat. While studying the effect of continuous application of chemical fertilizers with and without farmyard manure (FYM) and lime on maize wheat productivity, Subehia et al., (2005) found that continuous addition of 100 per cent $\mathrm{N}$ alone (urea) caused maximum damage and not even a single grain of maize or wheat could be harvested in that treatment whereas, application of FYM and lime along with NPK sustained higher grain yields as compared to sole use of inorganic fertilizers. 
In an Alfisol of Ranchi (Jharkhand), Mishra et al., (2008) found that the highest grain yields of wheat $\left(3.28 \mathrm{t} \mathrm{ha}^{-1}\right)$ was obtained with the application of 100 per cent NPK + lime which was at par with the yield obtained in 100 per cent NPK + FYM. Addition of FYM or lime along with inorganic fertilizer sustained higher crop yield and also improved the soil quality. Whereas, imbalance use of inorganic fertilizer $(100 \% \mathrm{~N})$ reduced crop productivity and nutrient uptake.

To assess the changes in soil fertility after 31 years of fertilizer use, a study was conducted by Behera and Singh (2009) at Delhi and they found that the grain and straw yields of wheat under 100 per cent NPK + FYM and 100 per cent $\mathrm{NPK}+\mathrm{Zn}$ were at par and higher as compared to other treatments. The long-term effect of nutrient management on productivity of rice (Oryza sativa) - wheat (Triticum aestivum) system was studied by Yadav and Kumar (2009) at Faizabad (Uttar Pradesh). They reported that the addition of organic manures along with chemical fertilizers sustained the wheat yield by increasing nutrients availability and nutrient use efficiency.

Verma et al., (2012) studied the changes in soil fertility status of maize-wheat system due to long-term use of chemical fertilizers and amendments in acid Alfisol of Palampur (Himachal Pradesh). They reported that the use of either FYM or lime along with 100 per cent NPK sustained the crop productivity and imbalanced use of nutrients i.e. NP or $\mathrm{N}$ alone adversely affected the fertility of soil by aggravating the problem of soil acidity.

In permanent manurial trial (PMT) initiated in 1956, in an Alfisol of Ranchi (Jharkhand), Kumari et al., (2013) studied the long-term effect of fertilizers, manure and lime on yield sustainability under maize-wheat cropping system. The highest grain yield of wheat (3.27 $\mathrm{t} \mathrm{ha}^{-1}$ ) was recorded in lime amended treatment and the reduction in grain yield of wheat over the years was noticed due to imbalanced application of fertilizers. Maximum reduction in grain yield was recorded in 100 per cent $\mathrm{N}$ followed by 100 per cent NP over 100 per cent NPK. Yang et $a l$. , (2015) examined crop yields after 22 years of long-term fertilizer experiment and they found that combination of inorganic and organic fertilizer substantially increased crop yields and it further increased with increasing the amount of fertilizer.

While studying the wheat yield trend in longterm rice-wheat cropping system in silt loam soil of Bhairahawa (Nepal), Rawal et al., (2015) reported that yields were consistently higher in NPK and FYM treatments than the treatments where one or more nutrients were lacking. They concluded that the productivity of the wheat can be increased and sustained by supplementing the nutrient through the integrated long-term use of organic and inorganic source. In Mollisol of Pantnagar (Uttrakhand), Bhatt et al., (2016) found that long-term integrated use of 100 per cent NPK with FYM sustained the yields under ricewheat cropping system. Hand weeding and application of $\mathrm{Zn}$ along with 100 per cent NPK was found to be superior over 100 per cent NPK in increasing rice and wheat productivity.

Over 41 years of study in silty clay loam soil of Pantnagar (Uttrakhand), Ram et al., (2016) reported that long-term integrated use of inorganic fertilizers and organic manure (FYM) was found superior in comparison with sole application of inorganic fertilizers in sustaining the crop productivity and soil fertility to enhance the soil quality in ricewheat cropping system. In an acid Alfisol of Palampur (Himachal Pradesh), Meena et al., (2017) conducted an experiment to study the effect of continuous application of fertilizers, farmyard manure and lime on soil fertility and productivity of the maize-wheat system and 
they found that continuous application of chemical fertilizers along with farmyard manure (FYM) or lime significantly influenced the yield and the uptake of nutrients by maize and wheat. Imbalanced use of fertilizers led to a significant reduction in the productivity and also depleted the soil fertility. From a similar study conducted by Rajneesh et al., (2017) on long-term effect of fertilizers and amendments in an acid Alfisol of North Western Himalayas, it was concluded that the application of 100 per cent NPK along with amendments (FYM/lime) recorded significantly higher NPK uptake over other treatments and imbalanced use of nutrients led to the reduction in the uptake of $\mathrm{N}, \mathrm{P}$ and $\mathrm{K}$. The impact of 21 years of continuous application of inorganic fertilizers and organic manure on sustainability of soybean-wheat cropping system, was studied by Choudhary et al., (2018) at Hawalbagh (Uttrakhand) and they reported that combined application of NPK + FYM resulted in significantly higher grain yield of soybean and wheat.

\section{Effect of fertilizers and amendments on wheat quality}

In acidic red soil of Ranchi (Jharkhand), the long-term effect of organic manures and fertilizers on quality of wheat was studied by Singh and Prasad (1977) and they found that potassium application decreased the calcium, phosphorus and boron contents of wheat grain, but increased the zinc content. Supplementing organic manures with phosphate fertilizers resulted in increase of calcium and phosphorus content of the grains.

Nedelciuc et al., (1995) studied the effect of fertilizers on protein content of wheat in chernozem soil of Romania and they reported that the grain crude protein content increased with increase in $\mathrm{N}$ rate, whereas, $\mathrm{P}$ fertilizer had no effect on protein content. Effect of organic and inorganic fertilization on wheat quality was studied by Ragasits et al., (2000) in Hungary and they reported that $\mathrm{N}$ fertilizer application (0-200 $\left.\mathrm{kg} \mathrm{N} \mathrm{ha}{ }^{-1}\right)$ influenced quality of wheat substantially and simultaneous application of FYM along with fertilizer increased the gluten content and its quality.

Singh et al., (2002) reported that the protein content of wheat grain increased significantly by 1.48 per cent with the application of farmyard manure @ 10 tonnes ha ${ }^{-1}$ and also enhanced the NPK content in wheat grain over control. In Typic Ustochrept of Kanpur, Dwivedi et al., (2002) found that the protein content increased significantly with increased use of $\mathrm{S}$ and $\mathrm{Zn}$ over control. Positive effects of application of FYM along with NPK on the protein and gluten content of grain were also reported by Blecharczyk and Malecka (2004) in Poland.

Long-term effect of NPK fertilizers on grain quality in winter wheat was studied by Dong et al., (2004) in China and they reported that the grain protein content decreased with the combined application of $\mathrm{N}$ and $\mathrm{P}$ fertilizers as compared to sole application of nitrogen. Gluten and grain protein increased with the application of $\mathrm{N}$ and $\mathrm{K}$ fertilizers, indicating the importance of balanced nutrition in soil. In a long-term field experiment at Beijing (China), the effect of long-term fertilizer use on the quality of wheat was studied by Huan et al., (2004) in grey desert soil of China and they reported that application of N, NP, NK and NPK increased the grain quality as compared to control. Omission of $\mathrm{N}$ reduced the contents of crude protein, essential amino acids and deteriorated flour and dough quality. Sahay et al., (2005) studied the longterm effect of manuring and fertilization on $\mathrm{S}$, $\mathrm{N}$ and protein content of wheat at Ranchi (Jharkhand) and they found that continuous use of manure enhanced the $\mathrm{S}$ content both in 
grain and straw. Higher protein content $(13.15 \%)$ was observed with half dose of FYM along with chemical fertilizers.

Pepo et al., (2005) also studied the baking quality parameters in long-term fertilizer experiment in chernozem soil in Hungary and they found that $\mathrm{N}$ fertilization increased the wet gluten content. Mars et al., (2006) evaluated the effect of $S$ fertilizer on the quality (gluten and protein content) of wheat and they found that application of $S$ fertilizer had no significant effect on quality. Baking quality parameters especially dough formation was better in treatments where $\mathrm{S}$ was added as compared to control.

The effect of NPK fertilization on quality parameters of winter wheat c.v. Zitarka in sandy loam soil of Donji Miholjac in eastern Croatia was studied by Hovart et al., (2006) and they concluded that protein content increased significantly with the application of $\mathrm{N} @ 80,120,160 \mathrm{~N} \mathrm{ha}^{-1}$ and wet gluten content was also significantly affected. Channabasanagowda et al., (2008) evaluated the effect of organic manures on quality of wheat and recorded significantly higher protein content in treatment receiving vermicompost + poultry manure and recommended dose of fertilizers (13.23\%). The increase in seed quality with application of vermicompost and poultry manure was attributed to better nutrient availability and its uptake by plant. The protein content of maize was significantly higher $(9.94 \%)$ in the chemical fertilized treatment at 100:50:30 kg ha $^{-1}$ of $\mathrm{N}, \mathrm{P}_{2} \mathrm{O}_{5}$ and $\mathrm{K}_{2} \mathrm{O}$ as compared to other treatments and the lowest protein content of 8.58 per cent was noted under control (Ramesh et al., 2008).

Influence of long-term $\mathrm{N}$ fertilization on micronutrient density of wheat grain was studied by Shi et al., (2010) and they reported that $\mathrm{N}$ fertilization increased $\mathrm{Fe}, \mathrm{Zn}$ and $\mathrm{Cu}$ density and protein concentration in wheat grain as compared to control but did not affect the Mn concentration. Vuscan (2010) reported that the lower potassium rates $\left(\mathrm{K}_{40}\right.$ and $\left.\mathrm{K}_{80}\right)$ influenced the dry gluten content of winter wheat positively in preluvo soil conditions of North-West part of Romania. The best value of the dry gluten content was obtained with $\mathrm{N}_{160} \mathrm{P}_{80} \mathrm{~K}_{80}$.

In Mollisol of Uttarakhand, a field experiment was conducted by Das et al., (2012) to study the effect of long-term application of inorganic fertilizers and manure on grain quality of wheat under rice-wheat cropping system and they found that the application of optimal dose of NPK along with Zn (100\% $\mathrm{NPK}+\mathrm{Zn}$ ) resulted in better grain quality in comparison to sole application of NPK fertilizers. Balanced application of fertilizer nutrients and combined use of inorganic fertilizers and manure enhanced the grain quality of wheat over sole use of NPK fertilizers.

In clay loam soil of Udaipur, Meena et al., (2013) found significant increase in crude protein, $\mathrm{HCN}$, crude fiber, fat and mineral ash contents of wheat under recommended dose of fertilizers through inorganic fertilizer + biofertilizer over control. In an experiment conducted to study the effect of zinc fertilization on quality of wheat grown in Jabalpur (Madhya Pradesh), Keram et al., (2013) found that the quality parameters like crude protein, wet gluten and total carbohydrate in wheat grain were markedly improved by increasing level of $\mathrm{Zn}$ as compared to NPK alone. Application of Zn @ $10 \mathrm{~kg} \mathrm{ha}^{-1}$ along with 100 per cent NPK maintained the quality of wheat grain.

Dhaliwal et al., (2015) reported that the use of organic manures either alone or in combination with fertilizers improved all the quality parameters of wheat grain except the 
protein content which was more in treatment receiving chemical fertilizers. A field experiment was conducted to study the effect of long-term fertilization and soil amendments on grain quality of wheat on acidic pseudogley of Kraljevo region (Serbia) by Jelic et al., (2015) and they found that the combined use of NPK fertilizers (120:60:40), lime $\left(5 \mathrm{t} \mathrm{ha}^{-1} \mathrm{CaCO}_{3}\right)$ and manure $\left(20 \mathrm{t} \mathrm{ha}^{-1}\right)$ positively affected grain quality in winter wheat.

Effect of zinc on yield and quality of wheat cultivars in Akola (Maharashtra) was studied by Bhujade et al., (2016) and they reported that the protein content in wheat grain was significantly higher due to the soil application of $\mathrm{ZnSO}_{4} @ 50 \mathrm{~kg} \mathrm{ha}^{-1}$ along with two foliar sprays of $\mathrm{ZnSO}_{4} @ 0.5$ per cent. In a deep black soil of Dharwad (Karnataka), effect of soil and foliar application of zinc and iron on productivity and quality of wheat was studied by Pallavi and Sudha (2017) and they concluded that soil $\left(20 \mathrm{~kg} \mathrm{ha}^{-1}\right)$ and foliar application of zinc $(0.5 \%)$ at heading and milking stage was the best agronomic practice in order to obtain higher quality of crop.

Effect of different nutrient management practices on quality of wheat (Triticum aestivum L.) was studied by Akhtar et al., (2018) in clayey soils of Junagarh (Gujrat) and they reported significantly higher protein content under the treatment 100 per cent NPK $+\mathrm{ZnSO}_{4} @ 25 \mathrm{~kg} \mathrm{ha}^{-1}$.

The integration of chemical fertilizers with organics/lime resulted in the highest yield of wheat. Imbalanced use of fertilizers resulted in significant decline in yield of wheat. Wheat quality parameters improved with integrated use of organic and inorganic fertilizers. Also, the application of organics (FYM) enhanced all the quality parameters.

\section{Acknowledgment}

The authors are extremely thankful to Indian Council of Agricultural Research, New Delhi (India) for the financial help and technical guidance to carry out this research work at CSK Himachal Pradesh Agricultural University, Palampur, Himachal Pradesh (India) under the aegis of "All India Coordinated Research Project on Long Term Fertilizer Experiment.

\section{References}

Akhtar, N., Ramani V.B., Yunus M. and Femi, V. 2018. Effect of different nutrient management treatments on growth, yield attributes, yield and quality of wheat (Triticum aestivum L.). International Journal of Current Microbiology and Applied Sciences 7: 3473-3479.

Behera, S.K. and Singh, D. 2009. Effect of 31 years of continuous cropping and fertilizer use on soil properties and uptake of micronutrients by maize ( $\mathrm{Zea}$ mays)-wheat (Triticum aestivum) system. Indian Journal of Agricultural Sciences 79: 264-267.

Bhatt, B., Chandra R., Ram S. and Pareek, N. 2016. Long-term effects of fertilization and manuring on productivity and soil biological properties under rice (Oryza sativa)-wheat (Triticum aestivum) sequence in Mollisols. Archives of Agronomy and Soil Science 62: 11091122.

Bhujade, P., Lahria G.S., Gore R.P., Hadole S.S, Hadke P., Bhendeand V. and Patil, R. 2016. Effect of zinc on yield and quality of wheat cultivars. Bioinfolet 13: 639-642.

Blecharczyk, A. and Malecka, I. 2004. Effect of long-term fertilization on grain quality of winter wheat grown continuously and in crop rotation. 
Works Scope of Agricultural Sciences 97: 25-31.

Channabasanagowda, N.K., Patil B, Patil B.N., Awaknavar J. S., Ninganur B. T. and Hunje, R. 2008. Effect of organic manures on growth, seed yield and quality of wheat. Karnataka Journal of Agricultural Sciences 21: 366-368.

Choudhary, M., Panday S.C., Meena V.S., Singh S., Yadav R. P., Mahanta D., Mondal T., Mishra P. K., Bisht J. K. and Pattanayak, A. 2018. Long-term effects of organic manure and inorganic fertilization on sustainability and chemical soil quality indicators of soybean-wheat cropping system in the Indian mid-Himalayas. Agriculture, Ecosystems and Environment 257: 3846.

Curti, E., Carini E., Tribuzio G. and Vittadini, E. 2014. Bread staling: effect of gluten on physico-chemical properties and molecular mobility. Food Science and Technology 59: 418-425

Das, T., Ram S. and Sirari, P. 2012. Effect of long-term application of inorganic fertilizers and manure on yields, nutrients uptake and grain quality of wheat under rice-wheat cropping system on a Mollisol. Pantnagar Journal of Research 10: 174-180.

Dhaliwal, J.K., Saroa G.S. and Dhaliwal, S.S. 2015. Effect of nutrient management practices on wheat grain quality under basmati rice-wheat system. Agricultural Research Journal 52: 43-47.

Dong, J., TingBoD, J. Qi, C. WeiXing, Z. Hui, Z. Qin, F. XueMei, C. RongZhen, F. GuoHua, L. DongTao and AiJun, Z. 2004. Effects of long-term combined application of $\mathrm{N}, \mathrm{P}$ and $\mathrm{K}$ fertilizer on grain quality in winter wheat. Scientia Agriculture Sinica 37: 566-571.

Dwivedi, S.K., Singh R.S. and Dwivedi, K.N. 2002. Effect of sulphur and zinc nutrition on yield and quality of maize in Typic Ustochrept soil of Kanpur. Journal of the Indian Society of Soil Science 50: 70-74.

Hovart, D., Loncaric Z., Vukadinovic V., Drezner G., Bertic B. and Dvojkovic, K. 2006. The influence of mineral fertilization on winter wheat yield \& quality. Cereal Research Communications 34: 429-432.

Huan, Q., BingQiang Z., YuHai C., Hua L., XiuYing L. and FuDao, Z. 2004. Effect of long-term fertilizer use on the yield and quality of wheat in grey desert soil. Plant Nutrition and Fertilizer Science 10: 12-17.

Jelic, M., Milivojevic J., Nikolic O., Djekic V. and Stamenkovic, S. 2015. Effect of long-term fertilization and soil amendments on yield, grain quality and nutrition optimization in winter wheat on an acidic Pseudogley. Romanian Agricultural Research 32: 165-174.

Keram, K.S., Sharma B.L., Sharma G.D. and Thakur, R.K. 2013. Impact of zinc application on its translocation into various plant parts of wheat and its effect on chemical composition and quality of grain. Academic Journals 8: 2218-2226.

Kumari, G., Thakur S.K., Kumar N, and Mishra, B. 2013. Long-term effect of fertilizer, manure and lime on yield sustainability and soil organic carbon status under maize (Zea mays) - wheat (Triticum aestivum) cropping system in Alfisols. Indian Journal of Agronomy 58: 152-158.

Leo, S., Frankie P, Kathryn O.S. and Jenny, W. 2012. Wheat bran: its composition and benefits to health, a European Prospective. International Journal of Food Science and Nutrition 63: 10011013.

Mallick, S.A., Azaz K., Gupta M., Sharma V., and Sinha, B.K. 2013. Characterization of grain nutritional quality in wheat. 
Indian Journal of Plant Physiology 18: 183-186.

Mars, E., Sipos P, Toth A and Gyori, Z. 2006. Quality and yield of winter wheat with sulphur content formulations. Cereal Research Communications 34: 577-580.

Meena, H.M., Sharma R.P, Sankhyan N.K., and Sepehya, S. 2017. Effect of continuous application of fertilizers, farmyard manure and lime on soil fertility and productivity of the maizewheat system in an acid Alfisol. Communications in Soil Science and Plant Analysis 48: 1552-1563.

Meena, R.M., Dashora L.N, Dhaker R.C., and Meena, B.P. 2013. Effect of integrated nutrient management on quality parameters of fodder yield in Sorghum (Sorghum bicolor L. moench). Annals of Agri Bio Research 18: 325-327.

Mishra, B., Sharma A, Singh S.K., Prasad J., and Singh, B.P. 2008. Influence of continuous application of amendments to maize-wheat cropping system on dynamics of soil microbial biomass in Alfisol of Jharkhand. Journal of Indian Society of Soil Science 56: 71-75.

Nedelciuc, M., Nedelciuc C., and Toma, M. 1995. Protein content and NPK consumption in wheat. Romanian Agricultural Research 3: 93-100.

Oluwatoyin, O.O., Afam I.O, Jideani and Daniso, B. 2015. Composition and functionality of wheat bran and its application in some cereal food products. International Journal of Food Science and Technology 50: 2509-2518.

Pallavi, V. and Sudha, T. 2017. Effect of soil and foliar application of zinc and iron on productivity and quality of wheat. Journal of Farm Sciences 30: 49-51.

Pepo, P., Sipos P., and Gyrori, Z. 2005. Effect of fertilizer application on baking quality of winter wheat varieties in a long-term experiment under continental in Hungary. Cereal Research
Communications 33: 825-832.

Poudel, R. and Bhatta, M. 2017. Review of nutraceuticals and functional properties of whole wheat. Journal of Nutrition and Food Sciences 7: 571.

Ragasits, I., Debreczeni K., and Berecz, K. 2000. Effect of long-term fertilisation on grain yield, yield components and quality parameters of winter wheat. Acta Agronomica Hungarica 48: 155163.

Rajneesh, Sharma R.P., Sankhyan N.K., and Kumar, R. 2017. Long-term effect of fertilizers and amendments on depthwise distribution of available NPK, micronutrient cations, productivity and NPK uptake by maize-wheat system in an acid Alfisol of North Western Himalayas. Communications in Soil Science and Plant Analysis 48: 21932209.

Ram, S., Singh V. and Sirari, P. 2016. Effects of 41 years of application of inorganic fertilizers and farm yard manure on crop yields, soil quality and sustainable yield index under a rice-wheat cropping system on Mollisols of North India. Communications in Soil Science and Plant Analysis 47: 179-193.

Ramesh, P., Panwar N.R., Singh A. B., and Ramana, S. 2008. Effect of organic manures on productivity, nutrient uptake and soil fertility of maize (Zea mays L.) linseed (Linum usitatissimum) cropping system. Indian Journal of Agricultural Sciences 78: 351-354.

Rawal, N., Chalise D., Tripathi J., Khadka D. and Thapa, K. 2015. Wheat yield trend and soil fertility status in long term ricerice-wheat cropping system. Journal of Nepal Agricultural Research Council 1: 21-28.

Sahay, S., Singh B.P. and Kumar, B. 2005. Long-term effect of manuring and fertilization on productivity, S content, $\mathrm{N}$ content and protein content of wheat. 
Crop Research (Hisar) 30: 364-368.

Shi, R., Zhang Y, Chan X, Sun Q, Zhang F, Romheld V and Zou, C. 2010. Influence of long-term nitrogen fertilization on micronutrient density in grain of winter wheat. Journal of Cereal Science 51: 165-170.

Singh, M. and Khatkar, B. 2005. Structural and functional properties of wheat storage proteins: a review. Journal of Food Science and Technology 42: 455471.

Singh, R., Agarwal S.K and Jat, M.L. 2002. Quality of wheat (Triticum aestivum) and nutrient status in soil as influenced by organic and inorganic sources of nutrients. Indian Journal of Agricultural Sciences 72: 456-460.

Singh, V.N. and Prasad, C.R. 1977. The longterm effect of manures and fertilizers on quality of wheat grown in acidic soils. Proceedings of the Bihar Academy of Agricultural Sciences 25: 12-17.

Sramkovaa, Z., Gregovab E. and Sturdika, E. 2009. Chemical composition and nutritional quality of wheat grain. Acta Chimica Slovaca 2: 115 - 138.

Subehia, S.K., Verma S. and Sharma, S.P. 2005. Effect of long-term use of chemical fertilizers with and without organics on forms of soil acidity, phosphorus adsorption and crop yields in an acid soil. Journal of the Indian Society of Soil Science 53: 308-314.

Tiwari, A., Diwedi A.K. and Dikshit, P.R. 2002. Long-term influence of organic and inorganic fertilization on soil fertility and productivity of soybeanwheat system in a Vertisol. Journal of Indian Society of Soil Science 50: 472475.

Verma, G., Sharma R.P., Sharma S.P., Subehia S.K. and Shambhavi, S. 2012. Changes in soil fertility status of maizewheat system due to long-term use of chemical fertilizers and amendments in an Alfisol. Plant Soil and Environment 58: 529-533.

Vuscan, A. 2010. The effect of $\mathrm{K} \times \mathrm{NP}$ fertilizers in long-term field experiments, on winter wheat yield and its quality in the preluvo soil conditions from North-West part of Romania. Research Journal of Agricultural Science 42: 354-358.

Yadav, D.S. and Kumar, A. 2009. Long-term effect of nutrient management on soil health and productivity of rice-wheat system. Indian Journal of Agronomy 54: $15-23$.

Yang, Z.C., Zhaoa N, Huang F and Lv, YZ. 2015. Long-term effects of different organic and inorganic fertilizer treatments on soil organic carbon sequestration and crop yields on the North China Plain. Soil \& Tillage Research 146: 47-52.

Zhang, W., Gu J. and Wang, Z. 2017. Comparison of structural and functional properties of wheat starch under different soil drought conditions. Scientific Reports 7: 12312.

\section{How to cite this article:}

Neha Chauhan, N.K. Sankhyan, R.P. Sharma and Gourav. 2020. Productivity and Quality of Wheat as Affected by Long-Term Addition of Fertilizers and Amendments: A Review. Int.J.Curr.Microbiol.App.Sci. 9(01): 2369-2377. doi: https://doi.org/10.20546/ijcmas.2020.901.270 